\title{
GEOGRAPHIC INFORMATION SYSTEMS IN FUNCTION OF ENVIRONMENTAL PROTECTION
}

\author{
Blagoja Markoski*, Svemir Gorin \\ Ss. Cyril and Methodius University in Skopje, Faculty of Natural Sciences and Mathematics, \\ Institute of Geography, Skopje, Republic of Macedonia \\ ${ }^{*}$ Corresponding author, e-mail: blagojamarkoski@gmail.com
}

\begin{abstract}
Geographical information systems as a methodology is a relatively new technology in scientific research and finding practical solutions for geographical problems. One of those problems is the complex over categorical set [1] known as environment. It is a very actual and complex problematic, hard for organizing and optimization when it has to set about the needs of humanity.

Therefore, this article deals with the application of geographic information systems as one of the latest scientific techniques and technologies through which one can analyze and define the most optimal solutions in terms of environmental protection and sustainable development.

The aim is to highlight the quantitative and qualitative aspects of GIS technology in function of the environment on the one hand, and through concrete examples to point out to the power of these technologies in the process of finding optimal solutions. It is briefly pointed out to some general criteria that are inevitable in the process of creating databases in GIS necessary for adequate and suitable GIS analyses.
\end{abstract}

Key words: geographic information systems; environmental protection; cartographic bases; databases; GIS analysis

\section{INTRODUCTION}

Geography as a science that studies space with all its physical, geographical, socio-economic and population elements, has been existing and evolving throughout the history of humankind. But it reached particularly important place during and after the great geographical discoveries. The periods from the 15th to the 19th centuries were mainly characterized by sea and land journeys and expeditions in search and discovery of unknown and new geographic areas. Typical examples were the discovery of America, Magellan's trips around the earth, breaking Africa's penetration into the interior of the continents and their colonization, the latest conquest of the North Pole in 1909 and the South Pole in 1911.

On the newly discovered territories there were established colonial holdings mainly under the administration of Great Britain, France, Spain, Portugal, Netherlands, Belgium and insignificant few other countries. This uneven division of the world was the cause of two world wars, which despite the horrors that war brings, they moves technological, and economic and political development of the countries and their colonies. Thus in the 20th century numerous countries have become independent on all continents, especially in Africa and South America.

In terms of the development in that period (approximately half of the 20th century) the information media of geography as a science (besides classical geographical studies) were assigned the role of introducing facts as a basis for obtaining information in sense, what country, what kind of natural resource possesses [15]. All this was established in order to promote greater economic and trade exchanges and cooperation. But the process of progress of telecommunications was so fast, that the facts in geography rather lost the classical sense. Geographic data has risen enormously so that their classical management became difficult. As a result of that, 
geography geographical cartographic representation upgraded a system from different geographic alphanumeric databases. It was fostered by the new computer and information technologies.

In that way methodologies, techniques and technology of geographic information systems emerged. In the last 20-30 years, they present new research and methodological direction of development in geosciences which defines the sense that geographical information system is a scientific methodology and technology that collects, enters, stores, processes, updates, analyzes, interactively links and displays spatial and other data in cartographic, graphic, photographic, tables and alpha, numeric and alphanumeric form spatial and other data in order to create new information and output products also in alpha, numeric and alphanumeric, tabular, graphic and cartographic form [2]. In this context GIS appears as a necessity in the area of environment.

\section{GEOGRAPHICAL INFORMATION SYS- TEMS AND ENVIRONMENT}

Geographic information systems are subsystems of the system man-nature-society, so that they treat the problem of geosphere, sociosphere, tehnosphere [11, 12, 13] and over categorical set [1], with their primary and secondary subsystems.

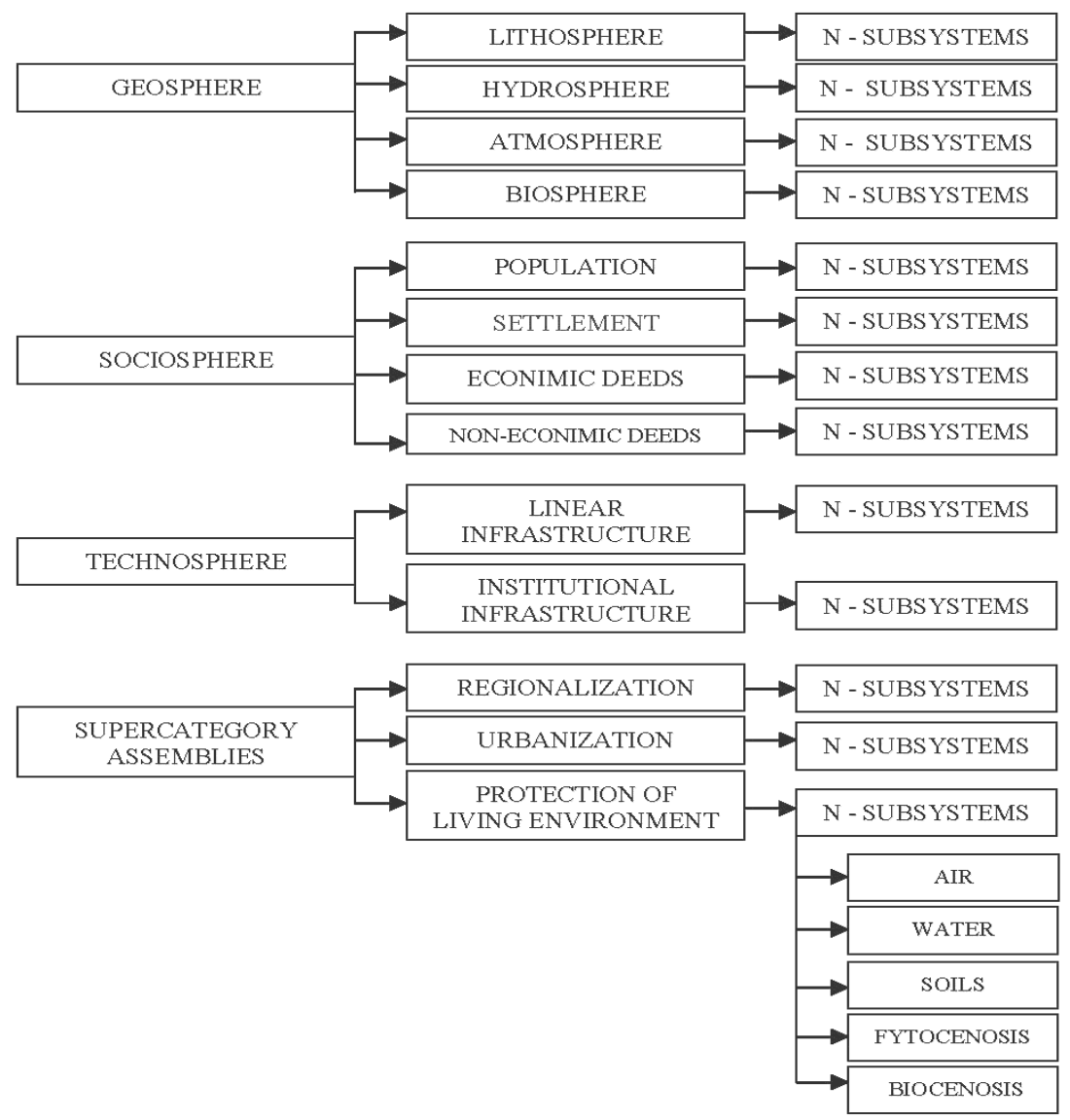

Figure 1. Global scheme of geographic information systems [2]

As it can be seen from the scheme, in spite of the large number of subsystems, in the over categorical set subsystem the environment is a separate subsystem [14].

The subsystem of GIS known as the environment, actually represents a quite extensive geographic information system, because it provides the subsystems of pollution and protection of air, wa- ter, soil, flora and fauna [3]. All these segments are vital to the survival and evolution of the species, and in this context to the survival and development of humanity. Because of such vital importance of these segments of the environment, GIS, with its power for geographic location through cartographic representation and connection with huge databases for each segment separately and as a whole, ap- 
pears as a very effective tool for fast, easy and efficient recording and analysis of situation, update and prediction of various scenarios [4]. So GIS has a close connections with and large application in the environment.

\section{MAIN OBJECTIVE OF THE GIVEN PROBLEM}

Problems in the environmental management of the earth, through numerous demographic and technical and technological developments become more and more complicate every day.

In the context of the given problem, GIS in function of environment main goals and objectives are distinguished.

The main objective is the inclusion of all available resources in the protection of the environmental management, thereby, including the organization and the establishment of a geographic information system.

Specific objectives (in order to realize the main objective) are:
- registration of environmental pollutants,

- identification of vulnerable areas in terms of pollution of air, water, land, flora and fauna,

- measures for environmental protection.

\section{METHODS AND METHODOLOGY}

Starting from the previously established objectives in the process of organizing and establishing a GIS in environment several methods were used including: geography; mapping; information; statistics; analysis and synthesis etc. The GIS methodologies are separate ones.

\section{ORGANIZATION AND ESTABLISHMENT OF GIS IN THE ENVIRONMENT}

The environment is a complex system which covers aspects of endangerment and protection of air, water, land, flora, fauna and noise. In order to establish a GIS, the elements of all subsystems of the environment are shown schematically below [5].

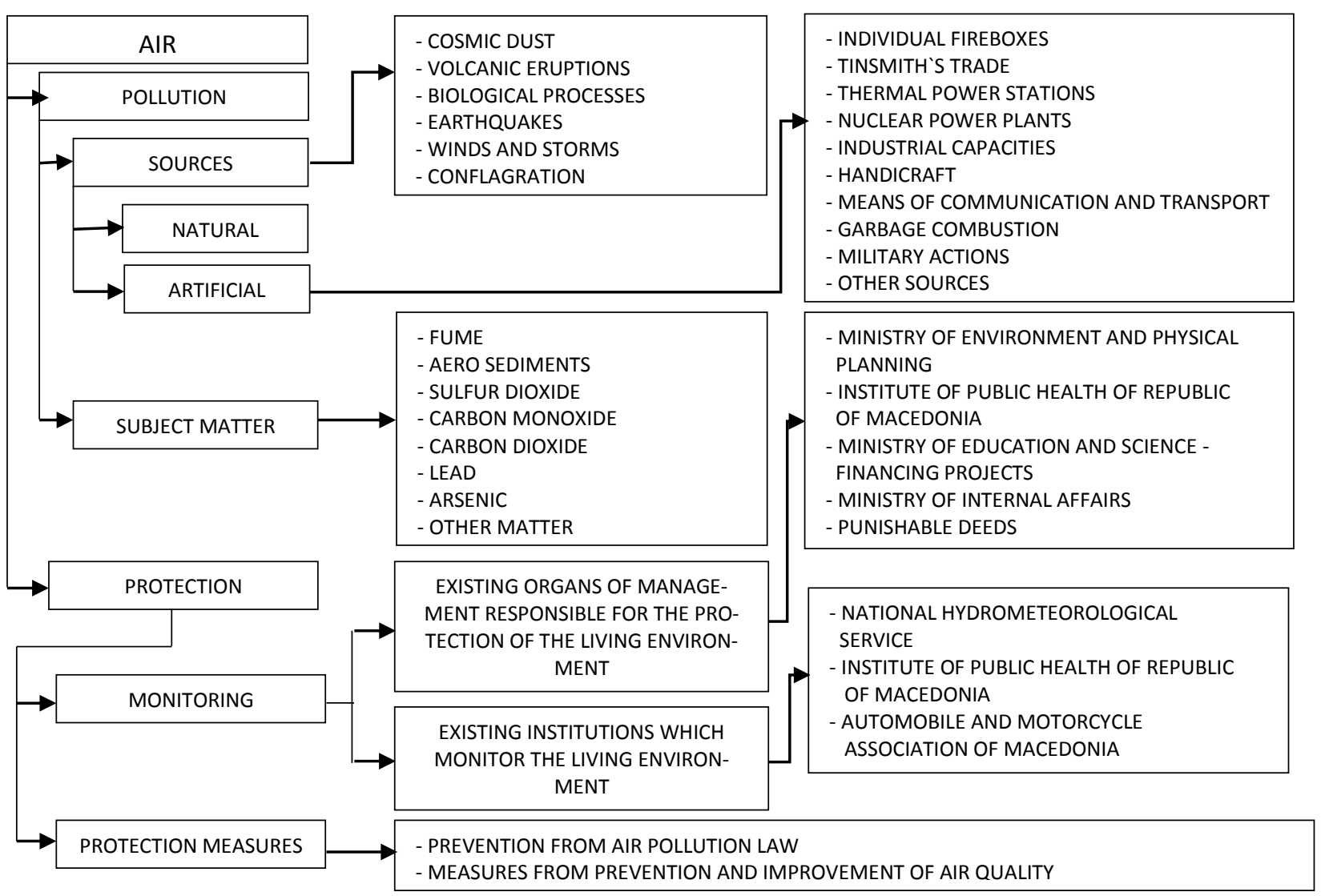

Figure 2. Organizational scheme for pollution and air protection [5] 


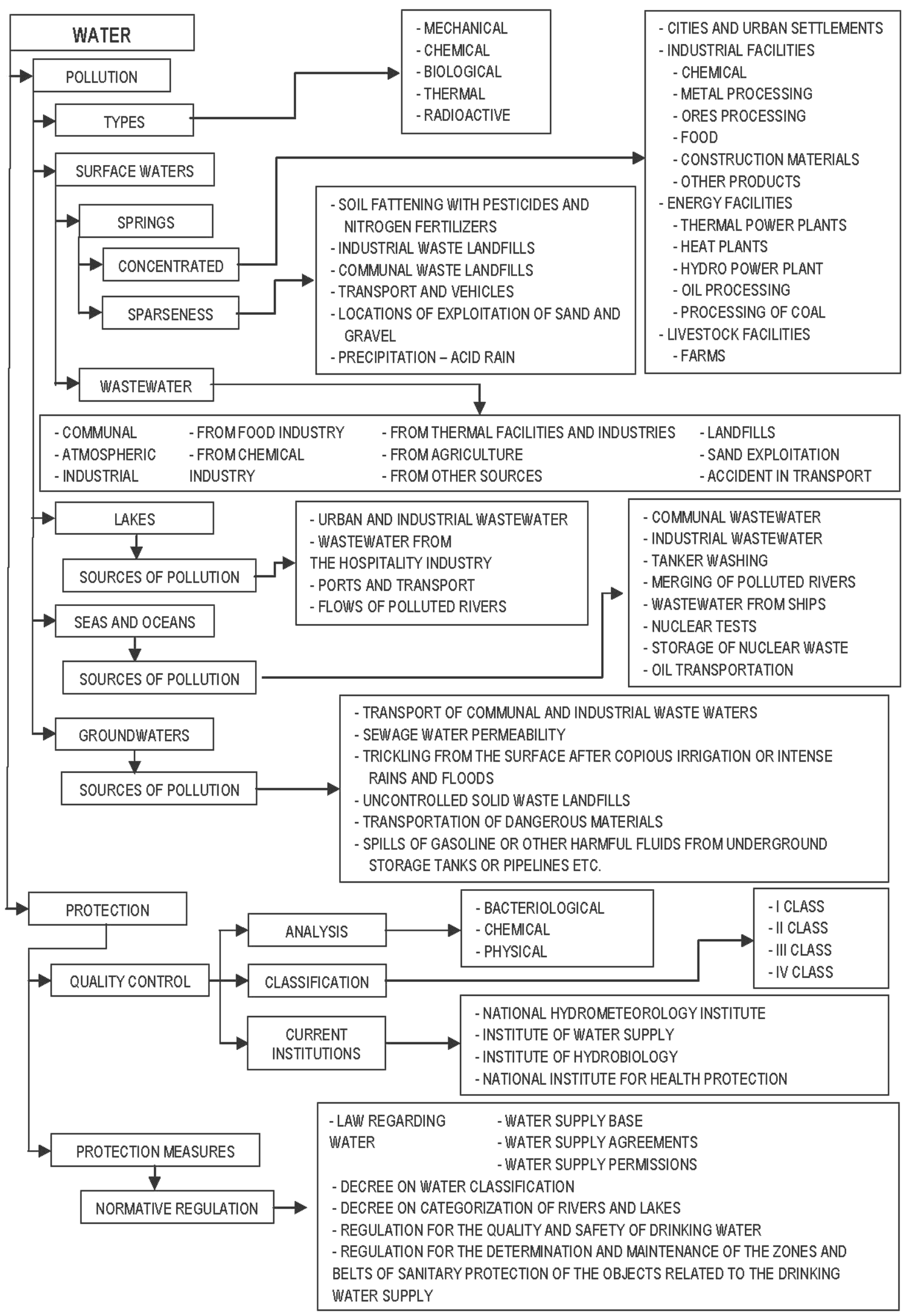

Figure 3. Organizational chart of pollution and protection of water [5] 


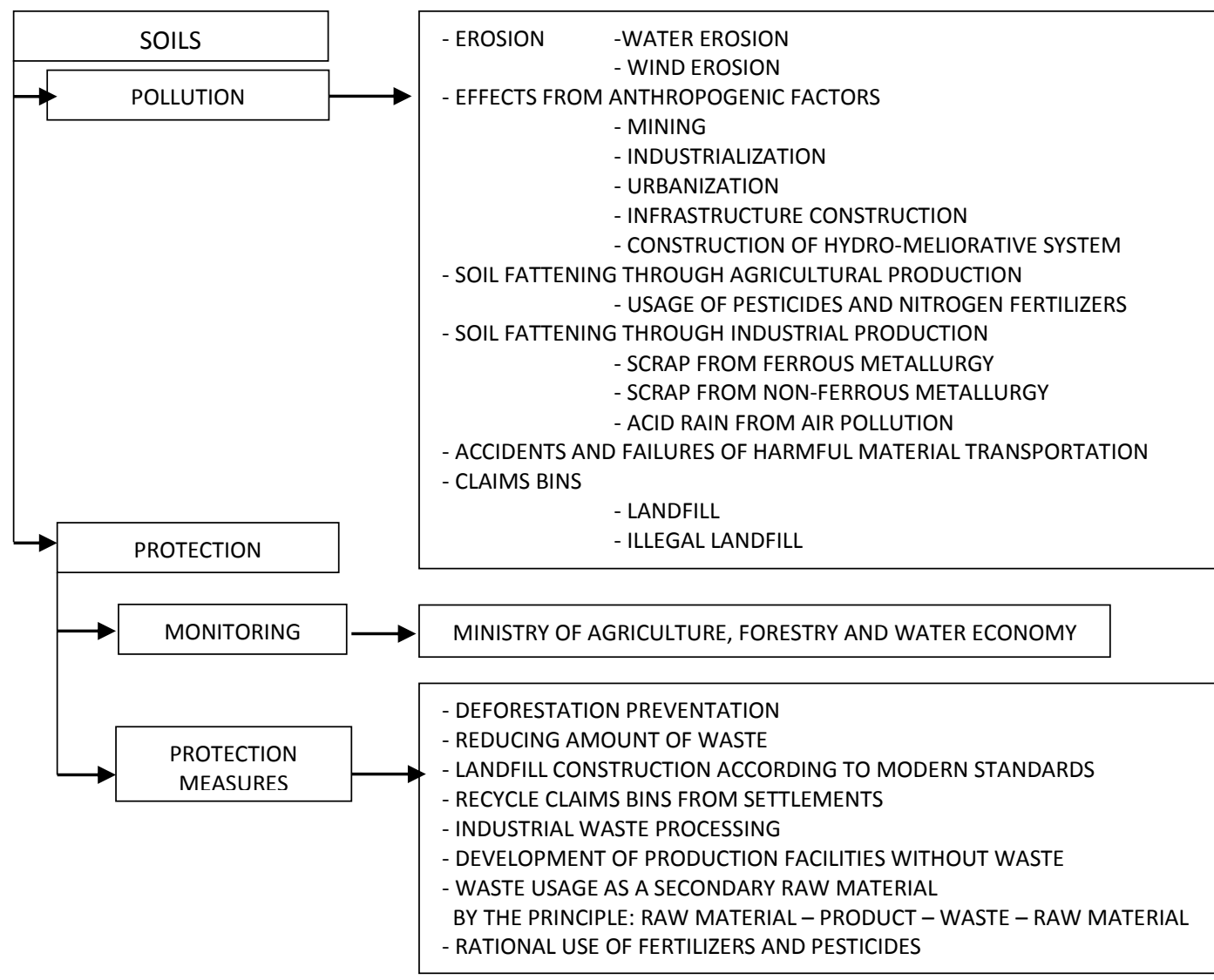

Figure 4. Organizational scheme of pollution and soil protection [5]

\begin{tabular}{|c|c|}
\hline ZOOCENOSIS & - CHANGING NATURAL CONDITIONS OF THE ENVIRONMENT AND DESTRUC- \\
\hline \multirow{2}{*}{ IMPERILMENT } & - INDUSTRALIZATION \\
\hline & - CITY CONSTRUCTION AND INFRASTRUCTURE SYSTEM \\
\hline PROTECTION & $\begin{array}{l}\text { - URBANIZATION } \\
\text { - CONSTANT HUNTING AND FISHING }\end{array}$ \\
\hline $\begin{array}{l}\text { PROTECTION } \\
\text { MEASURES }\end{array}$ & $\begin{array}{l}\text { - MEAT } \\
\text { - FUR } \\
\text { - LEATHER }\end{array}$ \\
\hline & $\begin{array}{l}\text { - BONES } \\
\text { - FEATHERS }\end{array}$ \\
\hline \multirow{2}{*}{$\begin{array}{l}\text { PROTECTION OF NATU- } \\
\text { RAL RARITIES LAW }\end{array}$} & $\begin{array}{l}\text { - GENETIC CHANGES OF THE NATURAL CHARACTERISTICS OF CERTAIN SPECIES } \\
\text { - GENETIC ENGINEERING }\end{array}$ \\
\hline & $\begin{array}{l}\text { - NATURE RESERVE } \\
\text { - NATIONAL PARKS } \\
\text { - STRICT NATURE RESERVES } \\
\text { - RESEARCH NATURAL RESERVES } \\
\text { - AREAS WITH SPECIFIC NATURAL PARITIES } \\
\text { - CHARACTERISTIC LANDSCAPES } \\
\text { - INDIVIDUAL PLANT SPECIES OUTSIDE THE NATIONAL PARKS }\end{array}$ \\
\hline \multirow[t]{2}{*}{ PHYTOCENOSIS } & - CHANGING NATURAL CONDITION OF THE ENVIRONMENT \\
\hline & $\begin{array}{l}\text { - HYDROACUMULATION SYSTEM CONSTRUCTION } \\
\text { - CITY CONSTRUCTION AND INFRASTRUCTURE SYSTEMS } \\
\text { - INDUSTRALIZATION }\end{array}$ \\
\hline \multirow{2}{*}{ IMPERILMENT } & - EXPLOTATION OF GRASS VEGETATION BY ANIMAL HUSBANDRY \\
\hline & - EXPLOATATION OF FORESTS BY THE SOCIAL AND INDIVIDUAL ECONOMY \\
\hline \multirow[t]{2}{*}{ PROTECTION } & $\begin{array}{l}\text { - ILLEGAL AND ILLEGAL LOGGING } \\
\text { - HARMFUL INSECTS }\end{array}$ \\
\hline & $\begin{array}{l}- \text { DROUGHT } \\
\text { - FIRES }\end{array}$ \\
\hline
\end{tabular}

Figure 5. Organizational scheme of pollution and protection of flora and fauna [5] 
Thus presented schemes are the basis for defining the algorithm for establishing the GIS. Through mapping methods the cartographic preparation for a specific GIS is realized [6], then across geographic methods, the physical, chemical and biological analyses identify the environment pollutants [7].
For the needs of GIS digital cartography they are processed, and parallel to it on the basis of structured elements of all subsystems individually they define all relevant attribute data as the basis for establishing the database.

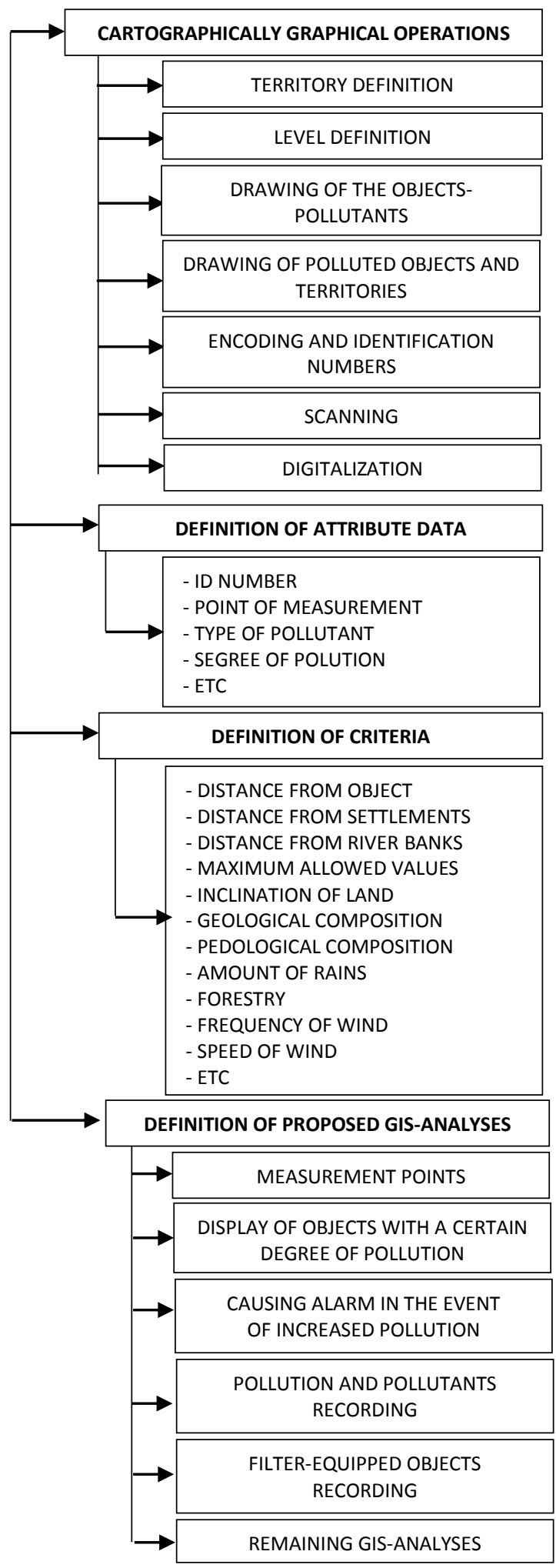

Figure 6. Cartographic operations attribute data, criteria and GIS analysis. 


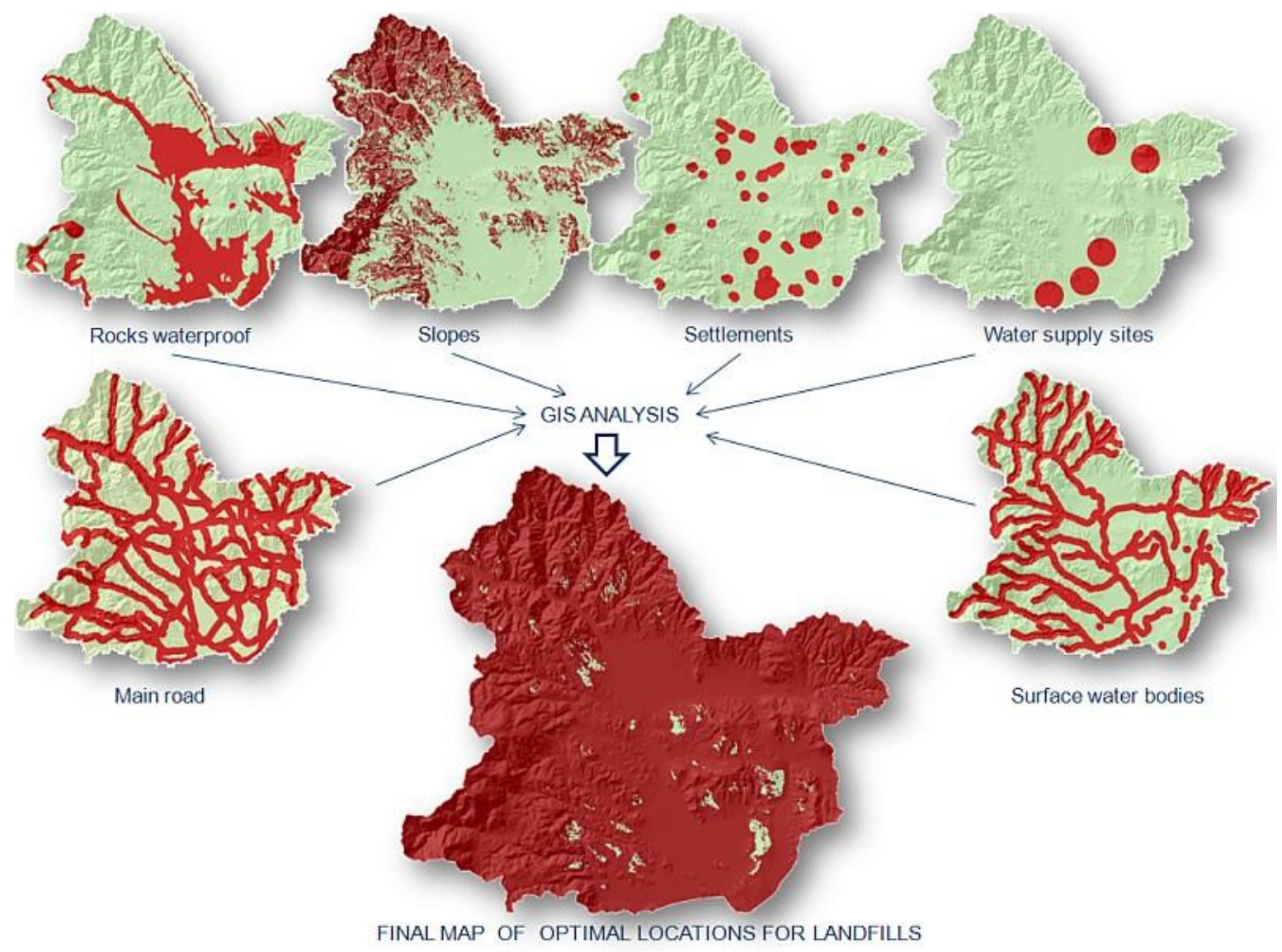

Figure 7. Functionality of GIS for optimal solutions (in the example, for the location of landfills of solid waste) [16]

The process of data collecting is implemented, and the data are inserted in the database through appropriate procedures and encryption, but also organized to allow establishing of different and specific criteria for functional analysis, such as, for example, criteria for location of landfills and factories, use of pesticides, etc. [6,7].

In addition, the overall cartographic basis with interactive mapping of the identified pollutants is connected to the database, so that the functionality of GIS is established.

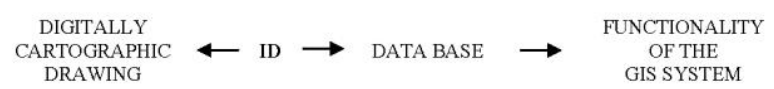

Figure 8. The main components of GIS operational system of the environment

\section{FUNCTIONALITY OF GIS IN THE ENVIRONMENT}

Through the geographically identified and mapped objects and areas that are endangered and their interaction with the database the GIS is formed as a whole. In that way established basis of the system is a dynamic functional unit, because it allows:

- Geographical overview of the density of buildings and endangered buildings and spaces;

- Queering of the map data base, from database into a map, according to various parameters (range of space, type of pollutants, etc.);

- Creation of new data by merging, intersection and overlapping of data, etc., so that new data are inserted in the database, and consequently the new analytical synthesis and cartographic products;

- Data analysis through which answers can be given to: where, which, however, zero, minimum, maximum, average, over, under, front, then, has not, can have, etc.;

- Data updating which involves a permanent system update with new measured data, so that temporal changes in the intensity of pollution can be traced besides the spatial ones.

Vital maintenance of such a large and functional Geographic Information System of environment allows to take timely measures for rehabilitation and removal of the problem of environmental pollution. 


\section{CONCLUSION}

The fast technical processes in the every day living and work of people, the increase in population, as well as the satisfying of existential needs cause large disturbances in the living environment. Such disturbances negatively affect the overall vital processes in nature and in men. The problem is brought into focus and the people are actively working in the field of preventive measures and protection of living environment.

Following previous experiences in the function of the living environment, in this paper an array of various schemes and illustrations regarding the processes of pollution and protection of all the components of the living environment, such as air, water, soil, flora and fauna, has been given.

The aforementioned schemes and illustrations are presented with an aim to:

- begin a process of organization and establishment of a geographic information system in the field of the living environment, and

- organize of an algorithm for an informatics-programming approach to the treatment of the cartographic and alphanumeric databases.

To this problem set various criteria are included such as the base for an automated search of optimal solutions related to the living environment, as well as the ordinary registered data, conclusions, researches, etc.

The function of the geographic information systems in the living environment is further enhanced by the opportunities for a permanent update of the data and offering notifications about the events that exceed the maximum allowed pollutant values.

\section{REFERENCES}

[1] Институт за просторно планирање, Мейодологија на научноисииражувачка рабой $а$, Просторен план на СР Македонија, Скопје, 1976 пп. 130.

[2] Б. Маркоски, Географски информациски сис$\bar{u} е м и$, Универзитет Св. Кирил и Методиј, Скопје, 2011, пп. 235.

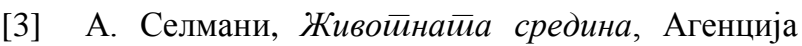
Скај, Скопје, 1994, пп. 200. А

[4] С. Манасов, Геоинформациски сисиееми, компјуйерско йроиесирање на информации за

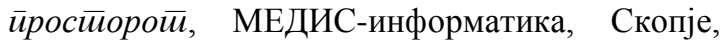
(1995), пп. 159.

[5] Б. Маркоски, О. Цековска, Алгоритам за воспоставување на еколошко информациски систем на Република Македонија како потсистем на Географскиот информациски систем од аспект на заштита и зачувување на животната средина, Зборник на йрудови од

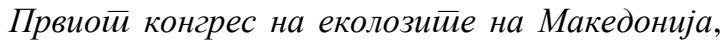
Охрид, 1998, пп. 917-923.

[6] С. Горин, Географски анализи базирани на

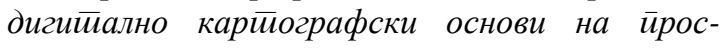
$\bar{u} о р о \bar{u}$ на Гевгелиско-валандовскайа койлина, Докторска теза, Универзитет Св. Кирил и Методиј, Скопје, 2013, пп. 203.

[7] 3. Илијовски, Мейодологија на израбойка на

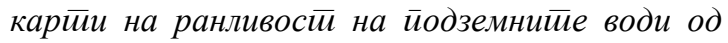
загадување, Докторска теза, Универзитет Св. Кирил и Методиј, Скопје, 2014, пп. 209.

[8] Б. Маркоски, С. Горин, ГИС во функција на руралниот развој на Република Македонија, Зборник на йрудови од научниой симйозиум со

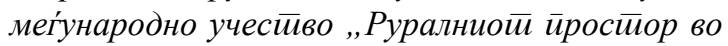

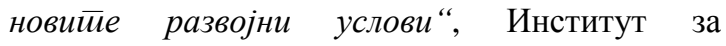
географија, ПМФ, Охрид, 2006.

[9] Б. Маркоски, Б. А. - Тошевска, Алгоритам за воспоставување информативен систем на индустријата во Република Македонија Зборник

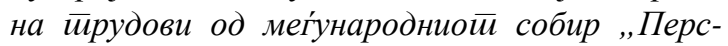
иекиииви и унайредување на ирросйорой“, Охрид, 1998, пп. 460-467.

[10] Б. Маркоски, Алгоритам за дигитално картографски третман на сообраќајниот систем на Република Македонија како потсистем на Географско информацискиот систем, Географски разгледи, кн. 35, Скопје, (2000), пп. 197-203.

[11] O. Bastian, Landscape Ecology-towards a unified discipline?. Landscape Ecology, 16, (2001), 757766.

[12] W. Manshard, Geography and the international global change programmes. European Review, 1, (1993), pp. 309-317.

[13] Z. Naveh, Biodiversity and landscape management. Biodiversity and Landscapes. A Paradox of Humanity, 1994, pp. 187-207.

[14] M. F. Goodchild, The state of GIS for environmental problem-solving. Environmental modeling with GIS, 1993, pp. 8-15.

[15] W. Bunge, Theoretical geography, Vol. 1, Royal University of Lund, Dept. of Geography; Gleerup, 1966.

[16] I. Milevski, O. Dimitrovska, B. Markoski, S. Gorin, Optimal landfill site selection as prevention of diseases. Medical Geography, Symposium with International Participation "Traditions and Modernity in Medical Geography and Disaster Medicine", Sofia, 2012, pp. 63-71. 


\section{ГЕОГРАФСКИТЕ ИНФОРМАЦИСКИ СИСТЕМИ ВО ФУНКЦИЈА НА ЖИВОТНАТА СРЕДИНА}

\section{Благоја Маркоски, Свемир Горин}

Универзитет „Св. Кирил и Методиј“, Природно математички факултет, Институт за географија, Скопје, Република Македонија

Географските информациски системи како метод се релативно нова технологија во научните истражувања и во изнаоѓањето практични решенија на географските проблеми. Еден од тие проблеми е комплексниот наткатегоријален склоп, познат како животна средина. Тоа е мошне актуелна и комплексна проблематика, тешка за организација и оптимизација кога ќе се постават во оптек потребите на човештвото.

Токму затоа во оваа статија станува збор за примена на географските информациски системи како една од најновите научни техники и технологии преку кои е можно да се анализираат и дефинираат најоптимални решенија во контекст на заштитата на животната средина и одржливиот развој. Целта е да се потенцираат квантитативните и квалитативните аспекти на ГИС како технологија во функција на животната средина, од една страна, и низ конкретни примери да се укаже на моќта на овие технологии во процесите на изнаоѓање на оптимални решенија. Накусо се укажува на некои општи критериуми кои се неминовни при процесите на креирање на базите на податоци во ГИС потребни за соодветни и издражани ГИС-анализи.

Клучни зборови: географски информациски системи; заштита на животната средина; картографски основи; бази на податоци; ГИС-анализи 
